\title{
Life Cycle Assessment and Quality of Utilization of Paint Waste as a Raw Material of Paving Block
}

\author{
Ari Dina Permana Citra ${ }^{1}$, Purwanto Purwanto ${ }^{1,2^{*}}$, Henna Rya Soenoko ${ }^{1}$ \\ 1 Doctorate Program of Environmental Science, School of Postgraduate Studies, Universitas Diponegoro, \\ Semarang 50241, Indonesia \\ 2 Department of Chemical Engineering, Faculty of Engineering, Universitas Diponegoro, Semarang 50275, \\ Indonesia \\ * Corresponding author's e-mail: purwanto@live.undip.ac.id
}

\begin{abstract}
The paint waste from the cosmetics packaging industry was sent to the third party for disposal by paying several management fees for hazardous waste. The use of paint waste as raw material for paving block products can reduce the environmental impacts and provide economic benefits. The life cycle assessment is a tool for measuring the environmental impact of this utilization compared to the management carried out by the third party. There are four scenarios reviewed that consist of third-party management, utilization as raw materials for paving block by the concentration of 1,2,3,4 and 5\% respectively. The analysis shows that the utilization of dry paint waste as a raw material for a paving block can reduce the impact of global warming and photo oxidant. The compressive strength value of paving blocks increased with the addition of the dry paint waste with the concentration of 1 and $2 \%$, then a slight decrease in proportion occurred with the addition of paint waste concentration up to $5 \%$. The addition of dry paint waste does not affect the water absorption with a range of $2 \%$, meeting the standard for a paving block.
\end{abstract}

Keywords: life cycle assessment, waste management, paint waste, waste to product, paving block

\section{INTRODUCTION}

Sustainable development is an issue related to economic, social and environmental aspects. Sustainable industrial development is directed to manage the environmental problems faced by the industry. Proper environmental management will reduce and minimize the negative environmental impacts, including the fulfillment of the environmental quality standards.

The environmental management approach evolved from a passive phase to a reactive approach by treating waste to meet the quality standards and obey laws and regulations, then towards proactive management based on pollution prevention, cleaner production and eco-efficiency models.

Industrial wastes are generally solid, liquid and gaseous with non-hazardous characteristics as well as hazardous and toxic wastes. The handling of the two types of waste is different, particularly in the case the hazardous waste, requiring high costs.

The waste management hierarchy begins with preventing the waste generation directly from its source, reducing the quantity of waste, managing it with reuse, recycling and recovery, and waste treatment is the last stage (Wenston and Stuckey, 1994).

The target of waste treatment is generally intended to comply with laws and regulations, thus contributing to the company's operational costs. The combination of environmental management with the economy known as eco-efficiency provides concurrent benefits both environmentally and economically in the form of savings in the operational costs (WBCSD, 2006).

Utilization of waste by turning it into useful products (waste to product) is an encouraging trend for industries, especially the use of 
hazardous waste as a raw material. In the cosmetics packaging industry, the waste generated from the packaging painting activities is hazardous and toxic. The industry, which is still having a problem for processing paint waste, sends it to a third party to be managed. The costs of having third parties manage the hazardous waste are high.

Some researchers studied the utilization of paint waste as raw material for manufacturing products (Johnson and Slater, 1990; Burton, 1993; McCarty,1993; Citra et al., 2018; Louis, 1996; Louis and Johnson, 1998; Nakouzi et al.,1998). The paint waste is used as a fuel that produces heat and as raw material for making ceramics and paving blocks. The processing for paving blocks involves a mixture of sand and cement with the addition of water, stirring and then compressing mechanically (Citra et al., 2018). The paint waste generated by the cosmetic packaging industry can be used as a mixture for making paving blocks (Purwanto and Citra, 2019).

The Life Cycle Assessment (LCA) methodology is used to evaluate environmental impacts comprehensively (Guinée et al., 2002). It can be applied to make decisions pertaining to the management of industrial environments. Various scenarios for waste management were carried out to calculate environmental impacts (Fikri et al., 2015; Sunarto et al., 2017). The LCA techniques were also been used to evaluate the environmental impact of managing and utilizing waste into products (Abeliotis et al., 2012; Astrup et al., 2015; Blengini et al., 2008; Chaya and Gheewala, 2007; De Feo and Malvano, 2009; Zhou et al., 2017; Pratikso et al., 2018)

This paper discusses the use of LCA to evaluate the environmental impact of the paint waste management and utilizing it as raw material in paving block production with various composition scenarios. The decision making on the use of paint waste for creating a paving block is using the evaluation result.

\section{MATERIALS AND METHODS}

\section{Characteristics of paint waste}

The paint waste is generated from the cosmetic industry located in Central Java Province. Then, through the LCA system, sand, cement, water and electricity are added to the paint waste from the cosmetic industry as inputs. The paint used in the packaging is an organic compoundbased paint, with the main ingredients consisting of ethylbenzene, propylene glycol methyl ether acetate, n-butyl acetate, 2-propenoic acid 2-ethyl $\mathrm{xz}$ and $1,2,3$ propanetryiltris $\mathrm{xy}$, and other ingredients to reach $100 \%$ composition. Table 1 shows the composition and characteristics of the paint waste used in this study.

\section{Waste management in the cosmetic packaging industry}

The management of the paint waste in the cosmetic packaging industry starts from reducing the waste that generated from the source, specifically the painting production process through improving the spray equipment and controlling the painting process. The system uses directional spraying with a precision setting of on-off time system to prevent the emergence of waste that is not attached to the packaging.

Currently, the paint waste in the liquid form is collected into special containers for hazardous waste and can be used as boiler fuel. However, the constraint is licensing the use of hazardous waste as fuel and monitoring the air emissions produced.

Delivering the paint waste to a third party is an easy solution for the company. However, this will be costly to transport from the industrial locations to the third party disposal locations. Furthermore, the environmental impacts during transportation, such as the greenhouse gases from the fuel combustion cause global warming, as well as other impacts during the treatment and disposal of the paint waste at a third-party location are unavoidable.

\section{Waste to product approach}

The waste management approach to the waste transformed into a useful product is a combination of economic and environmental aspects. The waste paint can be utilized as a useful product including fuel, a mixture of ceramic and paving

Table 1. Composition of Paint

\begin{tabular}{|l|c|}
\hline \multicolumn{1}{|c|}{ Substance } & Composition, \% \\
\hline Ethyl benzene & $5-10$ \\
Propylene glycol methyl ether acetate & $5-10$ \\
n-butyl acetate & $20-30$ \\
2-Propenoic acid 2-ethyl xz & $10-20$ \\
1,2,3 Propanetryiltris xy & $5-10$ \\
Others & $30-55$ \\
\hline
\end{tabular}


blocks. In this study, dried paint waste was used as raw material for paving block in which the mixtures varied from 1, 2, 3, 4 to $5 \%$ concentration.

\section{Life Cycle Assessment for Paint Waste}

In this research, LCA determines the environmental impact through processing the paint waste into paving block products with variations of $1,2,3,4$ and $5 \%$. Then, it compared the impact during the paint waste transportation and disposal. The environmental impact calculations use the SimaPro Education version, based on the Life Cycle Inventory (LCI) data. It calculates the impact of climate change and photo oxidant.

Utilization of the paint waste as a mixture of paving blocks uses four scenarios:

- First scenario if a third party takes paint waste for disposal

- The second scenario if the paint waste is used directly as a mixture of paving blocks with a mixture composition of $1 \%$.

- The third scenario if the paint waste is used directly as a mixture of paving blocks with a mixture composition of $2 \%$.

- The fourth scenario if the paint waste is used directly as a mixture of paving blocks with a mixture composition of $3 \%$.

- The fifth scenario if the paint waste is used directly as a mixture of paving blocks with a mixture composition of $4 \%$.

- The sixth scenario if the paint waste is used directly as a mixture of paving blocks with a mixture composition of $5 \%$.

LCA mainly emphasizes the environmental impact on the climate change in the form of the greenhouse gas potential that is expressed in tons of $\mathrm{CO}_{2}$ equivalent and photochemical oxidants in the form of volatile organic compounds (VOCs).

\section{RESULTS AND DISCUSSION}

\section{Life Cycle Assessment}

Licensed waste management companies perform management of paint waste through third parties. The paint waste is sent using land transportation, treated and disposed of, as shown in Figure 1. The environmental impact expressed by the potential for climate change through global warming is stated by the generation of greenhouse gases and photooxidant.
- Scenario 1: a third party takes paint waste for disposal

The distance of the location of the cosmetics packaging industry to the disposal site by a third party is $488 \mathrm{~km}$, using a truck vehicle with gasoline fuel. Then, the paint waste is managed on a 12 tons basis, causing the $\mathrm{CO}_{2}$ emissions of 1.7334 tons. Each $\mathrm{kg}$ of the paint waste will cause emissions during transportation of $0.1445 \mathrm{~kg} \mathrm{CO}_{2}$ eq.

The environmental impacts of the climate change from transportation per $1 \mathrm{~kg}$ of the paint waste amounted to $0.163 \mathrm{~kg} \mathrm{CO}$ eq and $39.7285 \mathrm{~kg}$ of $\mathrm{CO}_{2}$ eq caused by the paint waste (sludge).

- Scenario 1-5: paint waste as a raw material for paving block

The production of paving blocks requires raw materials of sand and cement in a ratio of $4: 1$ mixed with water. The mixture is stirred evenly, then pressed on the paving machine. The paving

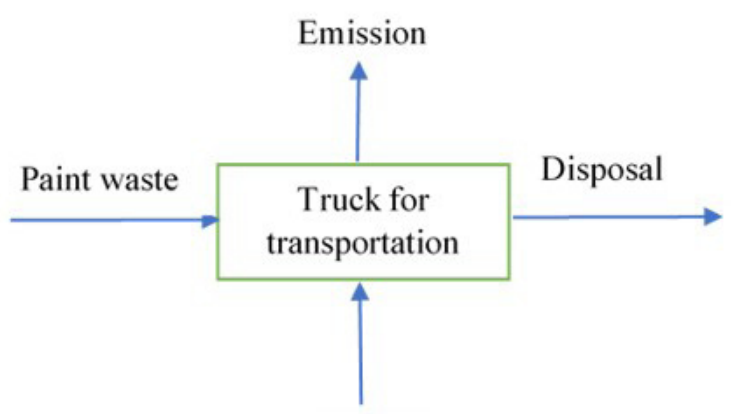

Fuel

Figure 1. Paint waste managed by the third party

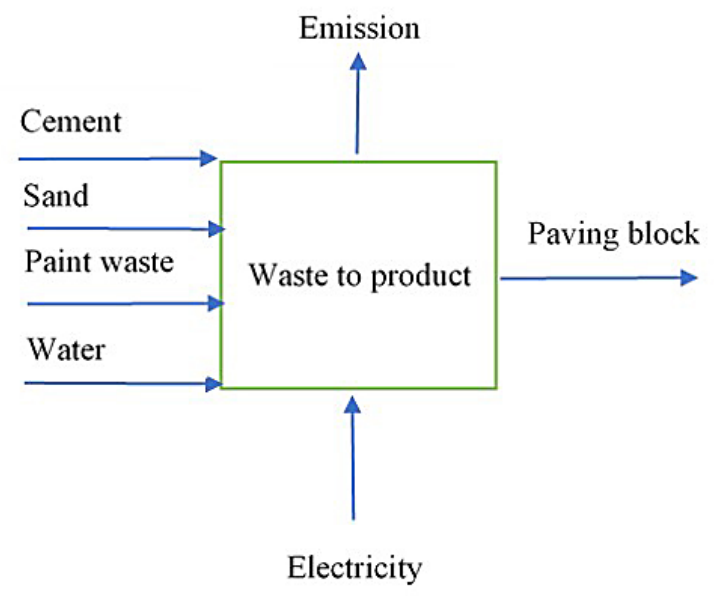

Figure 2. Utilization of paint waste as a raw material for paving block 
products with dimensions $21 \mathrm{~cm} \times 10.5 \mathrm{~cm} \times 6$ $\mathrm{cm}$ are atmospherically dried for 28 days so that the product can be used. The results of the LCA study conducted with four scenarios with and without the use of paint waste as a product are shown in table 2 .

The results of the impact study using LCA in Table 2 were calculated for every $1 \mathrm{~kg}$ of paving blocks. The paving produced with a percentage of waste paint mixture of $1,2,3,4$ and $5 \%$, has an impact on two categories, specifically the climate change and photochemical oxidant formation. The potential impact of the greenhouse gases decreases very significantly if the paint waste is used as a raw material for a mixture of paving blocks. Likewise, the effects of the photochemical oxidant formation decreased as well. From the environmental point of view, the use of the paint waste as raw material for these products yields positive benefits.

\section{Compressive strength of paving block}

The use of the paint sludge as a raw material for making paving blocks shows a decrease in the environmental impact, both as an impact of the climate change expressed in the generation of greenhouse gases as $\mathrm{CO}_{2}$ eq and in photochemical oxidants. Thus, the use of the paint waste as raw material for paving block provides a positive benefit for the environment, and the optimization of the percentage that can be used is measured by the compressive strength standards of paving blocks. The results of utilization are shown in Figure 3.

Figure 3 shows that the average compressive strength value of paving blocks has increased with the addition of dry paint waste at 1 and $2 \%$, then it slightly decreases in proportion to the addition of the paint waste concentration up to $5 \%$. The average compressive strength of paving with 5\% paint waste content is $244.55 \mathrm{~kg} / \mathrm{cm}^{2}$ compared to the paving without the paint waste mixture of $256.67 \mathrm{~kg} / \mathrm{cm}^{2}$ or a decrease of $4.72 \%$. Relatively, the use of $5 \%$ dry paint waste does not change the compressive strength of paving. On the basis of SNI 03-0691-1996, the paving blocks with a mixture of dry paint waste with a maximum content of $5 \%$ meet the quality of $\mathrm{B}, \mathrm{C}$ and $\mathrm{D}$ can be used as parking equipment, pedestrians, parks and others, but cannot be used as road pavement. Figure 3 shows the compressive strength of the paving block between $244-390 \mathrm{~kg} / \mathrm{cm}^{2}$. It is the highest compressive strength of the paving block with the paint waste mixture of $2 \%$ by weight.

Table 2. Environmental impact assessment uses LCA per $1 \mathrm{~kg}$ of paving blocks

\begin{tabular}{|l|c|c|}
\hline \multicolumn{1}{|c|}{ Scenario } & GHG potential & Photochemical oxidant formation \\
\hline Waste paint managed by the third party & $\begin{array}{l}0.163 \mathrm{~kg} \mathrm{CO}_{2} \text { eq (transportation) } \\
\text { and 39.892 kg CO }\end{array}$ & $0.136 \mathrm{~kg} \mathrm{NMVOC}$ (disposal)
\end{tabular}

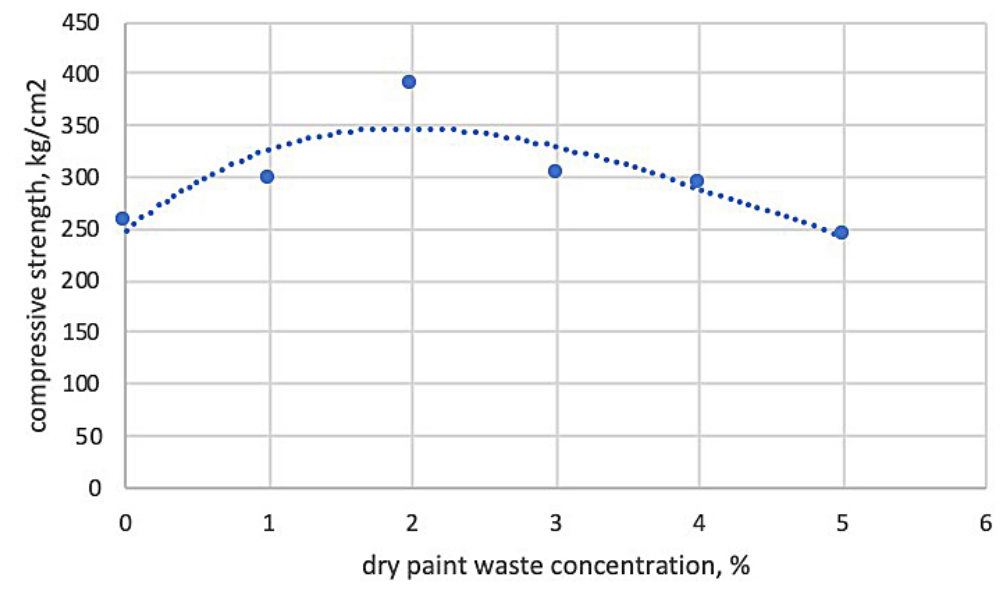

Figure 3. Compressive strength of paving blocks using a mixture of paint waste material. 


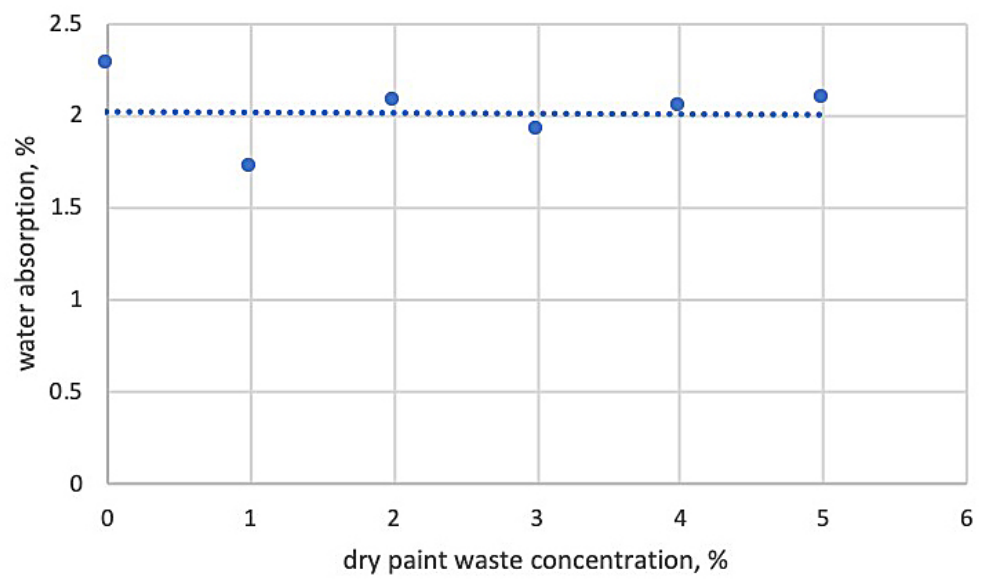

Figure 4. Water absorption of the paving blocks using a mixture of the paint waste material.

\section{Water absorption of pavinbBlock}

The water absorption test for the paving block with a mixture of dry paint waste is presented in Figure 4. It shows that the addition of the dried paint waste does not affect the absorption of water with a range of $2 \%$, due to the grains of paint and grinding sifting waste has a uniform size, resembling the sand used as the main ingredient of paving blocks. The use of paint wastes up to $5 \%$ levels yields the same compressive strength results as the case without the addition of paint waste and also does not change the absorption of water. Therefore, the dry paint waste that has been made in uniform size particles can be used as a mixture of making paving blocks. The water absorption standard, according to SNI 03-0691-1996 for category $\mathrm{A}$, is for the use of road pavement by $3 \%$.

\section{CONCLUSION}

The use of paint waste as raw material for paving blocks production can reduce the negative impact on the environment, particularly the potential of global warming and photochemical oxidants. Using paint waste into paving block mixture with a maximum of 5\% composition fulfilled the standard of compressive strength and water absorption. The waste to product approach provides economic and environmental benefits as an alternative to managing the industrial environment.

\section{Acknowledgements}

This research and publication were funded by Grant for Doctorate Research, Ministry of Research, Technology and Higher Education, Republic of Indonesia.

\section{REFERENCES}

1. Abeliotis K., A Kalogeropoulos A., Lasaridi K. 2012. Life Cycle Assessment of the MBT plant in Ano Li-ossia, Athens, Greece. Waste Management., 32, 213-219.

2. Astrup T.F., Tonini D., Turconi R., Boldrin A. 2015. Life cycle assessment of thermal waste-to-energy technologies: Review and recommendations. Waste Management, 37, 104-115.

3. Blengini G.A. 2008. Using LCA to evaluate impacts and resources conservation potential of composting. a case study of the Asti district in Italy, Resources, Conservation \& Recycling, 52, 1373-1381.

4. Burton R.E. 1993. Method for producing articles from waste fiber, waste/surplus paint, and waste/ surplus ink, US Patent 5,215,625

5. Chaya W., Gheewala S.H. 2007. Life cycle assessment of MSW-to-energy schemes in Thailand. Journal of Cleaner Production, 15, 1463-1468.

6. Citra A.D.P., Purwanto P., Soenoko H.R. 2018. The Use of Paint Waste as A Raw Material of Paving Block, E3S Web of Conferences, 73, 07001

7. De Feo G., Malvano C. 2009. The use of LCA in selecting the best MSW management system. Waste Management, 29, 1901-1915.

8. Fikri E., Purwanto P., Sunoko H.R. 2015. Modelling of household hazardous waste (HHW) management in Semarang city (Indonesia) by using life cycle assessment (LCA) approach to reduce greenhouse gas (GHG) emissions, Procedia Environmental Sciences, (23), 123-129

9. Johnson J.C., Slater A.1990. Methods for treating waste paint sludge, US Patent 4,980,030

10. Louis D.M.S.1996. Process for producing building materials from paint sludge, US Patent 5,573,587

11. Louis D.M.S and Johnson J.C. 1998. Method for processing paint sludge, US Patent 5,765,293

12. McCarty J., Hubb C., Peebles K.O. 2011. Processing 
paint sludge to produce a combustible fuel product, - US Patent 8,057,556

13. Purwanto P., Citra A.D.P. 2019. Recycling and processing of solid waste into products of the cosmetic packaging industry, Journal of Physics: Conference Series, 1

14. Pratikso P., Purwanto P., Sudarno S. 2018. Analysis Influence of Cement of the Asphalt Pavement Demolition Material on Roads Semarang-Demak Indonesia, Journal of Urban and Environmental Engineering 11 (1), 73-78

15. Sunarto S., Purwanto P., Hadi S.P. 2017. Quantification of Green House Gas Emissions from Municipal Solid Waste Recycling and Disposal in Malang City Indonesia, Journal of Ecological Engineering 18 (3), 74-82
16. Weston N.C., Stuckey D.C. 1994. Cleaner Technologies and The UK Chemical Industry, Institution of Chemical UK

17. WBCSD (World Business Council for Sustainable Development), 2006, http://docs.wbcsd. org/2006/08/EfficiencyLearningModule.pdf

18. Zhou Z., Tang Y., Chi Y., Ni M., Buekens A. 2017. Waste-to-energy: A review of life cycle assessment and its extension methods, Waste Management \& Research, 36 (1), 3-16

19. Nakouzi, S., D. Mielewski, J.C. Ball, B.R. Kim, I.T. Salemeen, D. Bauer, C.K. Narula, 1998, A novel approach to paint sludge recycling: Reclaiming of paint sludge components as ceramic composites and their applications in reinforcement of metals and polymers, Journal of Material Research, 13 (1), 53-60. 